\title{
EFFECTS OF JERUJU LEAVES EXTRACT (ACANTHUS ILICIFOLIUS) ON SANGKURIANG CATFISH (CLARIAS GARIEPINUS) INFECTED WITH AEROMONAS HYDROPHILA: CLINICAL SYMPTOMS AND DIFFERENTIAL LEUKOCYTES
}

\author{
Aisiah Siti ${ }^{\star}$, Rini Ririen Kartika, Olga, Wahyudi Deny \\ Study Program of Aquaculture, Faculty of Fisheries and Marine, \\ Lambung Mangkurat University, Banjarbaru, South Kalimantan, Indonesia \\ Tanod Wendy Alexander \\ Department of Fisheries and Marine, Politeknik Negeri Nusa Utara, Tahuna, \\ Sangihe Islands, North Sulawesi, Indonesia \\ *E-mail: sitiaisiah@ulm.ac.id
}

\begin{abstract}
This study aimed to determine the effect of ethanol extract of jeruju leaves on clinical symptoms and differential leukocytes of sangkuriang catfish infected with Aeromonas hydrophila. This research was conducted experimentally using a completely randomized design (CRD) consisting of five treatments and three replications. Sangkuriang catfish infected with $A$. hydrophila at a dose of $10^{8}$ cells $/ \mathrm{mL}$ via intraperitoneal injection. Then, the infected fish were treated with ethanol extract of jeruju leaves with concentrations $A=0$ $\mathrm{mg} / \mathrm{L}, \mathrm{B}=62.5 \mathrm{mg} / \mathrm{L}, \mathrm{C}=125 \mathrm{mg} / \mathrm{L}, \mathrm{D}=250 \mathrm{mg} / \mathrm{L}$ and $\mathrm{K}=$ control. Parameters observed were clinical symptoms and differential changes in leukocytes, including neutrophils, monocytes, lymphocytes, basophils, and eosinophils. The clinical symptoms of fish infected with $A$. hydrophila after being given jeruju leaves extract (according to the treatment concentration) recovered faster than those without the extract $(\mathrm{K})$. The differential leukocytes showed the highest percentage of neutrophils and monocytes at $250 \mathrm{mg} / \mathrm{L}$, basophils at 62.5 $\mathrm{mg} / \mathrm{L}$, the highest eosinophils at $125 \mathrm{mg} / \mathrm{L}$, and the percentage of lymphocytes did not differ between treatments. It can conclude that the extract concentrations of 125 and $250 \mathrm{mg} / \mathrm{L}$ were effective in stimulating differential leukocytes of sangkuriang catfish, which was indicated by an increase in the percentage of neutrophils and monocytes.
\end{abstract}

\section{KEY WORDS}

Sangkuriang catfish, hematology, differential leukocytes, jeruju, A. Hydrophila.

Disease outbreaks that attack farmed fish can cause huge losses. Outbreaks that often attack freshwater fish farming, including catfish, are Aeromonas hydrophila bacteria. Aeromonas hydrophila is an opportunistic pathogen that causes Motile Aeromonad Septicemia (MAS). MAS outbreaks can result in mass death in aquaculture. MAS disease generally attacks freshwater fish such as African catfish (Nitimulyo \& Triyanto, 1996), gourami (Mulia, 2005), goldfish (Maji et al., 2006), jambal siam (Olga et al., 2006), giant prawns (Abdolnabi et al., 2015), catfish (Pangasius hypophthalamus) (Olga et al., 2020).

In controlling MAS disease, the use of antibiotics in intensive cultivation systems has been prohibited. The prohibition of antibiotics is due to negative impacts such as immunosuppression and accumulation of residues in fish meat tissue and leads to pathogenic bacterial resistance (Harikrishnan et al., 2011). One of the safe ways to control motile aeromonad septicemia (MAS) disease in sangkuriang catfish aquaculture is by utilizing bioactive ingredients from natural products such as jeruju plant extract (Acanthus ilicifolius). The ethanol extract of jeruju leaves has been shown to have potential as an antibacterial of $A$. hydrophila in vitro and in silico by inhibiting the formation of the peptidoglycan membrane (Aisiah \& Rini, 2020). This study aimed to determine the effect of using ethanol extract of jeruju leaves (Acanthus ilicifolius) on clinical symptoms and differential leukocyte conditions in sangkuriang catfish infected with $A$. hydrophila. 


\section{MATERIALS AND METHODS OF RESEARCH}

The study was conducted from June to September 2021. The collection of jeruju leaves from the riverbanks of Kurau Village, Bati-Bati District, Tanah Laut, South Kalimantan, Indonesia. Then it is taken to the Fish Nutrition Laboratory and the Integrated Laboratory for extraction. Bacterial culture, clinical symptoms, and differential leukocytes were observed at the Laboratory of Fish Pests and Diseases, Faculty of Fisheries and Marine, Lambung Mangkurat University.

The jeruju leaves were cleaned, cut into small pieces, and dried at $50{ }^{\circ} \mathrm{C}$ until the leaves became dry. The dried leaves were crushed and extracted using a modified method based on Fatin et al. (2012) and Aisiah et al. (2020). $500 \mathrm{~g}$ of jeruju leaves powder maceration in $2000 \mathrm{~mL}$ of ethanol (Merck) for $4 \times 24$ hours. The mixture was then separated using Whatman 42 filter paper. The extracts obtained evaporated using a rotary vacuum evaporator at a temperature of $40^{\circ} \mathrm{C}$. Then, the extracts were stored in the refrigerator until they were ready for in vivo testing on infected sangkuriang catfish.

The challenge test was carried out using a completely randomized design. The concentration of jeruju leaves extract was determined based on the in vitro inhibition tests, namely the MIC, MBC, and toxicity tests on catfish (Aisiah \& Rini, 2020). Sangkuriang catfish infected with $A$. hydrophila at a density of $10^{8}$ cells $/ \mathrm{mL}$. Then soaked with jeruju leaves extract for 24 hours, as follows:

- $A=$ Without soaking jeruju leaf extracts $-0 \mathrm{mg} / \mathrm{L}$;

- $B=$ Soaking with jeruju leaf extracts at $62.5 \mathrm{mg} / \mathrm{L}$;

- $\quad C=$ Soaking with jeruju leaf extracts at $125 \mathrm{mg} / \mathrm{L}$;

- $\quad D=$ Soaking with jeruju leaf extracts at $250 \mathrm{mg} / \mathrm{L}$;

- $\mathrm{K}=$ Control without infected with $\mathrm{A}$. hydrophila and soaking with jeruju leaf extracts.

The observations were done against clinical and differential leukocyte symptoms, including neutrophils, monocytes, lymphocytes, basophils, and eosinophils from sangkuriang catfish.

\section{RESULTS OF STUDY}

Clinical symptoms of sangkuriang catfish for seven days, after the challenge assay (infected) of $A$. hydrophila and soaked in ethanol extract of jeruju leaves for 24 hours, are presented in Table 1.

Table 1 - Clinical symptoms of sangkuriang catfish after challenge assay (infected with A. hydrophila) and soaked in jeruju leaves extract

\begin{tabular}{|c|c|c|}
\hline \multirow{2}{*}{$\begin{array}{l}\text { Observation } \\
\text { Time }\end{array}$} & \multicolumn{2}{|l|}{ Clinical Symptoms } \\
\hline & Infected Fish, with Extract & Infected Fish, without Extract \\
\hline 12 hours & $\begin{array}{l}\text { Stretched fish fins, a balance was disturbed, swimming was } \\
\text { not normal, slow, eating response was reduced. }\end{array}$ & $\begin{array}{l}\text { Stretched fish fins, a balance was disturbed, } \\
\text { swimming was not normal, slow, eating response } \\
\text { was reduced. }\end{array}$ \\
\hline 24 hours & No feeding response and passive movement. & No feeding response and passive movement \\
\hline 36 hours & $\begin{array}{l}\text { There was no feeding response, passive movement, some fish } \\
\text { were inflamed in the area around the injection, and the fins are } \\
\text { slightly damaged. }\end{array}$ & $\begin{array}{l}\text { There was no feeding response, passive movement, } \\
\text { some fish were inflamed in the area around the } \\
\text { injection, and the fins are slightly damaged. }\end{array}$ \\
\hline 2 days & $\begin{array}{l}\text { some fish were still inflamed, the damage to the fins was } \\
\text { getting more visible, some fish had swollen organs, inactive } \\
\text { movements, and the response to eating was already there. }\end{array}$ & $\begin{array}{l}\text { Fish were still inflamed, damage to the fins, some } \\
\text { fish had swollen organs, inactive movements, and } \\
\text { poor response to food }\end{array}$ \\
\hline 3 days & $\begin{array}{l}\text { The fish still had inflammation, damage to the fins, swelling of } \\
\text { the organs, but some fish had started to be active and eat. }\end{array}$ & $\begin{array}{l}\text { Fish still had inflammation, swelling; significantly } \\
\text { reduced the response to eating. }\end{array}$ \\
\hline 4 days & $\begin{array}{l}\text { Inflammation began to subside; swelling heals, fish began to } \\
\text { swim normally and actively move. }\end{array}$ & $\begin{array}{l}\text { Fish are hemorrhagic, swollen, unresponsive to feed, } \\
\text { and inactive. }\end{array}$ \\
\hline 5 days & $\begin{array}{l}\text { Inflammation was getting smaller; fish was swimming normally } \\
\text { with active movements, response to feed was good. }\end{array}$ & Fish movement was slow and still hemorrhagic \\
\hline 6 days & $\begin{array}{l}\text { No more inflammation, active swimming fish, and good } \\
\text { response to feed. }\end{array}$ & $\begin{array}{l}\text { Inactive movement, poor response to eating, fish } \\
\text { were still hemorrhagic. }\end{array}$ \\
\hline 7 days & $\begin{array}{l}\text { No more inflammation, active swimming fish, and good } \\
\text { response to feed. }\end{array}$ & $\begin{array}{l}\text { Inactive movement, poor response to eating, fish } \\
\text { were still hemorrhagic. }\end{array}$ \\
\hline
\end{tabular}


The differential observation of leukocytes helps know the difference in the percentage of leukocyte cell components, including the number of neutrophils, monocytes, lymphocytes, basophils, and eosinophils. The percentage of neutrophils, monocytes, lymphocytes, basophils, and eosinophils found in the blood smear of sangkuriang catfish infected with $A$. hydrophila after 24 hours of soaking with jeruju leaves extract is presented in Figure 1.

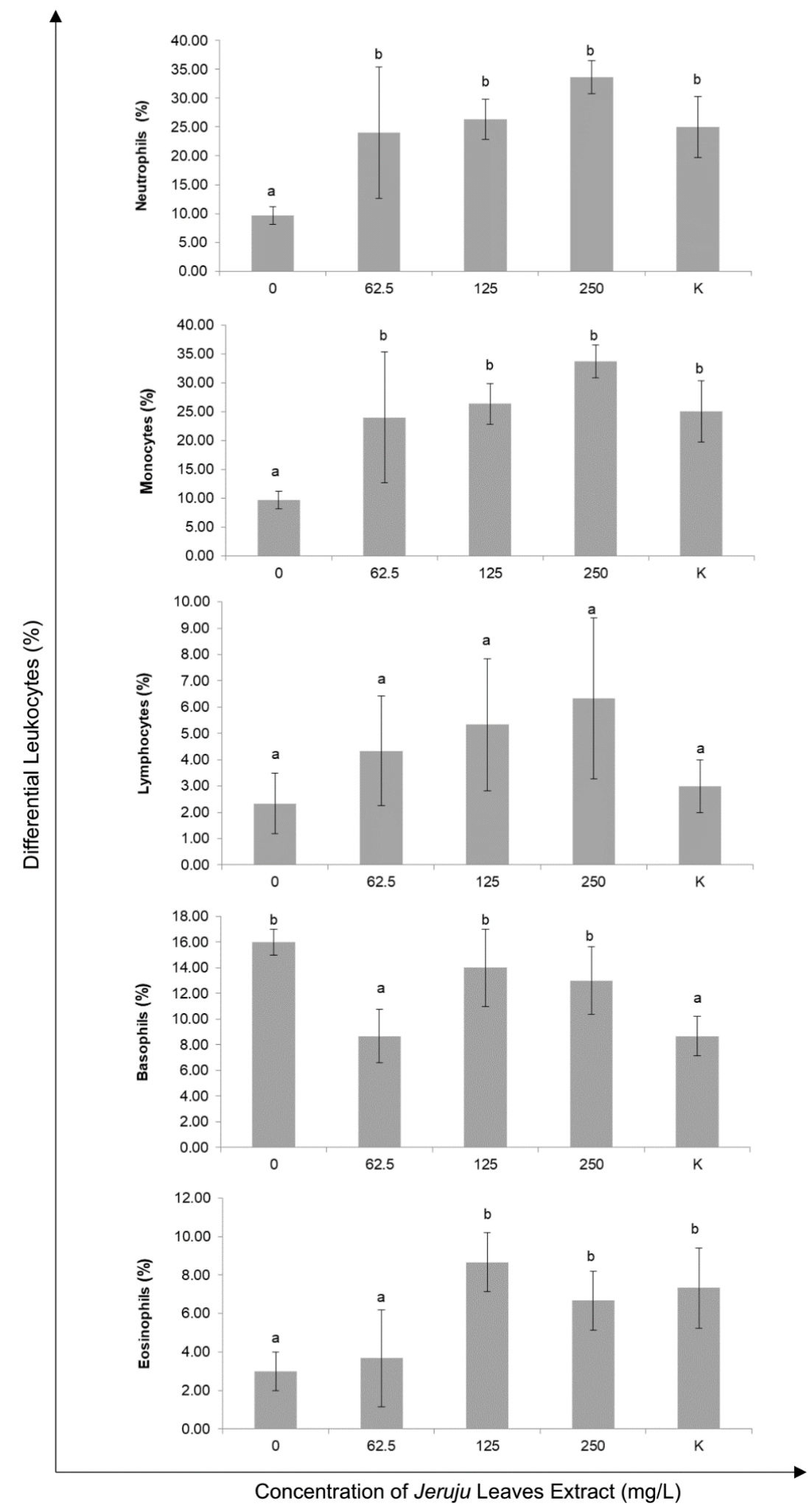

Figure 1 - Differential Leukocytes in Sangkuriang Catfish Infected with A. hydrophila and Soaking with Jeruju Leaves Extract for 24 Hours 


\section{DISCUSSION OF RESULTS}

The clinical symptoms shown by sangkuriang catfish after being infected with $A$. hydrophila were inflammation in the area around the injection, wounds that spread around the injection area, damaged fins, swelling (dropsy) occurred, reduced feeding response, and passive movement. Dana (2002) reported clinical symptoms of infection in fish, including empty intestines and did not form a long series, the appearance of changes in body color to become lighter, changes in swimming behavior, reddish tail, and damage to the caudal fin. Motile Aeromonad Septicemia caused by $A$. hydrophila causes various pathological conditions that include acute, chronic, and disguised infections. The severity of the disease is influenced by some interrelated factors, including the virulence of the bacteria, the type and level of stress exerted on the fish population, the physiological conditions of the host, and the level of genetic resistance inherent in a particular population of fish (Cipriano, 2001).

Leukocytes are the most active units of the body's defense system and circulate in the blood circulation in various types. The number of leukocytes is less than the red blood cells. The primary function of leukocytes is to destroy infectious and toxic materials through phagocytosis by forming antibodies. The types of leukocytes observed in this study included the percentage of neutrophils, monocytes, lymphocytes, basophils, and eosinophils. Harikrishnan et al. (2003) stated that leukocytes could protect infection from microbes and other chemical factors. Observation of leukocytes can generally explain the immune system and fish health status.

The percentage of neutrophils in the $250 \mathrm{mg} / \mathrm{L}$ extracts increased in tandem with the concentrations of $125 \mathrm{mg} / \mathrm{L}$ and $62.5 \mathrm{mg} / \mathrm{L}$ and was almost the same as in the treatment of healthy fish $(\mathrm{K})$ and decreased in infected fish $(0 \mathrm{mg} / \mathrm{L})$. The results of Duncan's Multiple Range Test (DMRT) showed that the percentage of healthy fish neutrophils $(K)$ was not different from the treatment with jeruju extract at all concentrations and significantly different from the treatment of infected sangkuriang catfish $(0 \mathrm{mg} / \mathrm{L})$. These results indicated that the extract administration affected and increased the number of neutrophils in infected fish.

The neutrophil percentage increased at $250 \mathrm{mg} / \mathrm{L}$, indicating the presence of phagocytic antimicrobial activity. Alamanda et al. (2007) stated that neutrophils play a role in the immune response to attacks by pathogenic organisms and have phagocytic properties. Neutrophils in the blood increase in the event of infection and act as the body's first line of defense. Next, Hrubec et al. (2000) stated that neutrophils play defense against bacterial infections. Neutrophils normally reside in lymphoid tissue and migrate to blood vessels when inflammatory stimuli occur. At the same time, Suhermanto et al. (2011) stated that the primary function of neutrophils is the destruction of foreign materials through phagocytic processes, namely chemotaxis by way of cells migrating towards particles or particle adhesion to cells, ingestion of particles by cells, and destruction of particles by lysosomal enzymes in phagolysosomes.

The percentage of monocytes increased in the $250 \mathrm{mg} / \mathrm{L}$ extract treatment, equivalent to $62.5 \mathrm{mg} / \mathrm{L}, 125 \mathrm{mg} / \mathrm{L}$, and healthy fish $(\mathrm{K})$. The DMRT test results showed that the infected sangkuriang catfish $(0 \mathrm{mg} / \mathrm{L})$ was significantly different from healthy fish $(\mathrm{K})$ and the treatment with extracts $(62.5,125$, and $250 \mathrm{mg} / \mathrm{L})$. The results of this study indicated that the extract could increase the percentage of sangkuriang catfish monocytes. Maftuch (2007) states that in the inflammatory process, when tissue damage by microbial infection or antigen-antibody reactions occurs, it can increase monocyte production to two times, and monocytes mature into macrophages more quickly, so they can immediately go to the inflamed tissue.

Monocytes $9.4-10.7 \mathrm{~m}$ in diameter, round or protruding, an eccentric nucleus exposed chromatin in the cytoplasm. Monocytes are highly basophilic and often have clear vacuoles in the cytoplasm. Monocytes function as precursors of macrophages and are active phagocytes. Lysosomal hydrolysis enzymes digest incoming material. Monocytes appear as irregular cells, have large nuclei and contain lots of chromatin. Monocytes migrate following the migration of granulocytes caused by inflammation (Hrubec et al., 2000). 
Monocytes function as macrophage precursors, monocytes-macrophages are active phagocytes. Incoming foreign material will be killed and digested by lysosomal hydrolysis enzymes. Monocytes-macrophages migrate following the migration of granulocytes stimulated by inflammation (Clauss et al., 2008). The increase in the percentage of monocytes during the infection process in the fish's body is caused by monocytes pushing and destroying foreign objects that enter, such as bacteria. Monocytes are cells in the bloodstream and develop into macrophages. When monocytes are activated, macrophages have a more vital phagocytic capacity than neutrophils, even though the number of granulocytes is more significant (Irianto, 2005).

DMRT test results showed that the percentage of lymphocytes did not differ between all treatments. However, there was an increasing trend in fish treated with $250 \mathrm{mg} / \mathrm{L}$. The average rate of lymphocytes that increased due to the administration of jeruju leaf extract indicated that the humoral immune response of sangkuriang catfish had recovered to a good condition, resulting in the process of resistance to bacterial infection with the formation of antibodies. Lymphocytes in the bloodstream migrate to the lymph or into the spleen. When they meet a foreign object, the lymphocytes will develop and undergo mitosis to become plasma cells that function as antibodies (Sadikin, 2002).

According to Hrubec et al. (2000), lymphocytes are essential cells in the immune response consisting of $B$ cells and $T$ cells. $B$ cells function as cells that produce antibodies, while $T$ cells function to control the immune response. The number of fish lymphocytes under stress conditions due to infection will decrease and trigger lymphopenia (Olga, 2009).

Lymphocytes are small cells with large nuclei and contain little cytoplasmlymphocytes found in fish, namely small and large lymphocytes. The diameter of small lymphocytes ranges from 4.6 to $5.0 \mu \mathrm{m}$, dark purple; the cytoplasm of lymphocytes is dark blue and often consists of only a thin circle surrounding the nucleus. Large lymphocytes have a diameter of 5.7 to $6.4 \mu \mathrm{m}$, larger round nuclei, and a more exposed chromatin pattern than small lymphocytes. The cytoplasm of large lymphocytes is deeper and more basophilic than that of small lymphocytes. Small lymphocytes and large lymphocytes have a high N:C ratio. Lymphocytes generally have cytoplasmic pseudopods and azurophilic cytoplasmic granules (Hrubec et al., 2000).

The results showed that the number of lymphocytes was lower in sangkuriang catfish infected with $A$. hydrophila bacteria. Bijanti (2005) explains that the decrease in lymphocyte cells is influenced by the presence of foreign antigens (such as bacteria), causes the immune system to be disturbed, and causes the number of lymphocytes to decrease. The decrease in lymphocytes is because lymphocytes are the body's first line of defense against infection (Alamanda et al., 2007).

The basophils percentage decreased in the treatment of $62.5 \mathrm{mg} / \mathrm{L}$ equivalents to healthy fish, while in infected fish, there was an increase of basophils equivalent to the treatments of $125 \mathrm{mg} / \mathrm{L}$ and $250 \mathrm{mg} / \mathrm{L}$. The results of the DMRT test showed that the treatment of healthy fish $(\mathrm{K})$ and $62.5 \mathrm{mg} / \mathrm{L}$ of jeruju leaf extract was significantly different from the treatment with extracts $(0,125$, and 250$) \mathrm{mg} / \mathrm{L}$. These results showed that jeruju leaf extract $62.5 \mathrm{mg} / \mathrm{L}$ reduced the number of basophils in infected fish and was equivalent to healthy fish.

Basophils are coarse basophilic granules in the cytoplasm with a round, cloudy nucleus. Basophil cells have a weak phagocytic ability and are often found in acute infectious conditions. Basophils are smaller in diameter than neutrophils, about 9-10 m, making up 1\% of the total white blood cells. Basophils have many cytoplasmic granules that cover the nucleus and contain heparin and histamine. In tissue, basophils become "mast cells." Basophils have immunoglobulin $G(\lg G)$ attachment sites, and their degranulation is associated with histamine release. Its function plays a role in allergic responses (Hoffbrand \& Pettit, 1996).

The percentage of eosinophils showed an increase in fish given extract $125 \mathrm{mg} / \mathrm{L}$, followed by $250 \mathrm{mg} / \mathrm{L}$ and healthy fish $(\mathrm{K})$. The results of the DMRT test showed that the treatment of infected fish $(0 \mathrm{mg} / \mathrm{L})$ was significantly different from the treatment of fish with extracts (125 and 250) mg/L and healthy fish. Meanwhile, the extract treatment of $62.5 \mathrm{mg} / \mathrm{L}$ 
was not significantly different. These results showed that jeruju extract 125 and $250 \mathrm{mg} / \mathrm{L}$ increased the number of fish eosinophils given the extracts and showed almost the same amount as healthy fish. According to Ramnik (2003), the estimated time for the formation of eosinophils is 2-6 days, and then the formed eosinophils are activated and can increase the fish's body defense. The lifespan of circulating eosinophils is 6-12 hours and will then survive in the tissue for two weeks. The results of clinical symptoms and leukocyte differential showed that jeruju leaves extract could cure sangkuriang catfish infected with A. hydrophila. Jeruju leaves extract can stimulate the performance of sangkuriang catfish leukocyte cells as an immune response to bacterial infection.

\section{CONCLUSION}

The findings concluded that there were differences in fish behavior and clinical symptoms in the speed of healing due to $A$. hydrophila infection from each treatment. The differential results of sangkuriang catfish leukocytes increased for the percentage of neutrophils and monocytes at $250 \mathrm{mg} / \mathrm{L}$ and eosinophils at $125 \mathrm{mg} / \mathrm{L}$. Both of these concentrations were effective concentrations to stimulate differential leukocytes of sangkuriang catfish infected with $A$. hydrophila.

\section{ACKNOWLEDGMENTS}

All authors would like to thank the Rector and Head of LPPM Lambung Mangkurat University for providing the opportunity to obtain non-tax revenue research funds through the Compulsory Research Lecturer Program with the source of funds from the University of Lambung Mangkurat DIPA for the 2021 fiscal year, No. SP DIPA-023.17.2.6777518/2021 dated November 23, 2020. By the Decree of the Rector of Lambung Mangkurat University Number: 697/UN8/PG/2021 dated March 22, 2021.

\section{REFERENCES}

1. Abdolnabi, S., Daud, H. M., Mariana, N. S., \& Abdelhadi, Y. M. (2015). Pathogenicity of Aeromonas hydrophila in giant freshwater prawn; Macrobrachium rosenbergii, cultured in East Malaysia, 14(1), 232-245.

2. Aisiah, S., Rini, R.K., (2020). Potensi Bioaktif Ekstrak Daun Jeruju (Acanthus ilicifolius) Sebagai Pengendali Penyakit Motile Aeromonad Septicemia Pada Ikan Patin (Pangasius hypophthalamus). Laporan Penelitian PNBP TA. 2020, Universitas Lambung Mangkurat Banjarbru, $85 \mathrm{pp}$.

3. Aisiah, S., Tanod, W. A., Salosso, Y., \& Riyadi, P. H. (2020, October). Computational analysis of ethyl acetate extract of Nauclea subdita (Korth.) Steud. leaves as peptidoglycan glycosyltransferase inhibitor in Aeromonas hydrophila. In IOP Conference Series: Earth and Environmental Science (Vol. 584, No. 1, p. 012022).

4. Alamanda, Intan Estetika, Noor Soesanti Handajani, and Agung Budiharjo. 2007. "Penggunaan Metode Hematologi Dan Pengamatan Endoparasit Darah Untuk Penetapan Kesehatan Ikan Lele Dumbo (Clarias Gariepinus) Di Kolam Budidaya Desa Mangkubumen Boyolali The Use of Hematology Method and Blood Endoparasite Observation for Determining." Seminar 8: 34-38.

5. Bijanti, Retno. 2005. Hematologi Ikan (Teknik Pengambilan Darah Dan Pemeriksaan Hematologi Ikan). Surabaya: Bagian Ilmu Kedokteran Dasar Vateriner Fakultas Kedokteran Hewan Universitas Airlangga.

6. Cipriano, C. Rocco. 2001. "Aeromonas hydrophila And Motile Aeromonad Septicemias Of Fish." In Fish Disease, Washington: United States Departemen Of The Interior, 65-97.

7. Clauss, Tonya M., Alistair D M Dove, and Jill E. Arnold. 2008. "Hematologic Disorders of Fish." Veterinary Clinics of North America - Exotic Animal Practice 11(3): 445-62.

8. Dana, D. 2002. "Peranan Ekstrak Kelopak Dan Buah Mangrove Sonneratia caseolaris (L.) Terhadap Infeksi Bakteri Vibrio harveyi Pada Udang Windu (Penaeus monodon 
FAB.)" 1(3): 129-38.

9. Fatin R., Wahab R., Daud J.M., Sudin M., Rasad M.S and Sulaman O., Study on Methanolic Extracts of Nauclea subdita ( Korth ) Steud. Heartwood Parts for the Total Phenolic Contents and Free Radical Scavenging Activities. Journal of Biological Sciences 4(5):600-607

10. Guyton, A.C. dan J.E. Hall. 1997. Buku Ajar Fisiologi Kedokteran Edisi 9. EGC, Jakarta.

11. Harikrishnan, R., M. Nisha Rani, and C. Balasundaram. 2003. "Hematological and Biochemical Parameters in Common Carp, Cyprinus carpio, Following Herbal Treatment for Aeromonas hydrophila Infection." Aquaculture 221(1-4): 41-50.

12. Harikrishnan, R., Balasundaram, C., \& Heo, M. S. (2011). Impact of plant products on innate and adaptive immune system of cultured finfish and shellfish. Aquaculture, 317(14), 1-15.

13. Hoffbrand, A.V., Petit J. E., Moss , Kapita Selekta Hematologi Edisi 4. Penerbit Buku Kedokteran EGC, Jakarta 2005Hrubec, T.C. dan S.A. Smith. 2000. Hematology of Fish. Schalm's Veterinary Hematology Fifth.

14. Hrubec, Terry C, Jenifer L Cardinale, and Stephen A Smith. 2000. "Hematology and Plasma Chemistry ReferencelrIntervals for Cultured Tilapia (Oreochromis Hybrid)." Veterinary Clinical Pathology 29(1): 1-12.

15. Irianto, Agus. 2005. Patologi Ikan Teleostei. Yogyakarta.: Penerbit Gajah Mada University press.

16. Maftuch. 2007. "Paparan Vibrio Alginolyticus Terhadap Histopatologi Usus Ikan Kerapu Tikus (Cromileptes altivelis) Dan Peningkatan Jumlah Serta Aktivitas Sel Makrofag." Jurnal Penelitian Perikanan Universitas Brawijaya, Malang. 10(1): 66-70.

17. Maji, S., Mali, P., \& Joardar, S. N. (2006). Immunoreactive antigens of the outer membrane protein of Aeromonas hydrophila, isolated from goldfish, Carassius auratus (Linn.). Fish \& Shellfish Immunology, 462-473.

18. Mulia, D. . (2005). Isolasi , Karakterisasi , dan Identifikasi Bakteri Aeromonas sp. Agen Kausatif Motile Aeromonas Septicemia ( MAS ) pada Gurami. Sains Akuatik, 13, 9-17.

19. Nitimulyo, K. H., \& Triyanto. (1996). Vaksinasi Aeromonas hydrophila untuk Menanggulangi Penyakit MAS pada Lele Dumbo (Clarias gariepinus). Jakarta: Prosiding Simposium Perikanan I. Buku II Bidang Budidaya Perikanan. Balitbang Pertanian.

20. Olga, O., Aisiah, S., A Tanod, W., Risjani, Y., Nursyam, H., \& Maftuch, M. (2020). Immunogenization of Heat-Killed Vaccine Candidate from Aeromonas hydrophila in Catfish (Pangasius hypophthalamus) using Strain of Banjar, South Kalimantan, Indonesia. Egyptian Journal of Aquatic Biology and Fisheries, 24(4), 1-13.

21. Olga, Rini, R. K., Akbar, J., Isnansetyo, A., \& Sembiring, L. (2006). Protein Aeromonas hydrophila sebagai Vaksin untuk Pengendalian MAS (Motile Aeromonas Septicemia) pada Jambal Siam (Pangasius hypophthalamus). Perikanan, (L), 17-25.

22. Olga. 2009. "Aktivitas Antibakteri Aeromonas hydrophila, Pseudomonas Sp Dan Vibrio Sp Dari Ekstrak Polar Daun Jambu Biji (Psidium guajava L.)." In Prosiding Seminar Internasional Hasil-Hasil Penelitian Tahun 2009., Purwokerto, 3 Mei 2009.

23. Ramnik S. 2003. Haematology for students and practitioners. 5th edition. New Delhi: Jaypee Brothers.

24. Sadikin, H.M. 2002. Biokimia Darah. Pertama. Jakarta: Widya Medika.

25. Suhermanto, Achmad, Sri Andayani, and Maftuch. 2011. "Pemberian Total Fenol Teripang Pasir (Holothuria scabra Untuk Meningkatkan Leukosit dan Diferensial Leukosit Ikan Mas (Cyprinus carpio) Yang Diinfeksi Bakteri Aeromonas hydrophila." 4(2): 150-57. 